\title{
Article
}

\section{Activation of Coronary Arteriolar PKC 32 Impairs Endothelial NO-Mediated Vasodilation: Role of JNK/Rho Kinase Signaling and Xanthine Oxidase Activation}

\author{
Naris Thengchaisri ${ }^{1,2}{ }^{\infty}$, Travis W. Hein ${ }^{1}$, Yi Ren ${ }^{1}$ and Lih Kuo ${ }^{1, *(1)}$ \\ 1 Department of Medical Physiology, Cardiovascular Research Institute, College of Medicine, Texas A\&M \\ University Health Science Center, Bryan, TX 77807, USA; ajnaris@yahoo.com (N.T.); thein@tamu.edu (T.W.H.); \\ yren@tamu.edu (Y.R.) \\ 2 Department of Companion Animal Clinical Sciences, Faculty of Veterinary Medicine, Kasetsart University, \\ Bangkok 10900, Thailand \\ * Correspondence: 1kuo@tamu.edu
}

check for updates

Citation: Thengchaisri, N.; Hein, T.W.; Ren, Y.; Kuo, L. Activation of Coronary Arteriolar PKC $\beta 2$ Impairs Endothelial NO-Mediated Vasodilation: Role of JNK/Rho Kinase Signaling and Xanthine Oxidase Activation. Int. J. Mol. Sci. 2021, 22, 9763. https://doi.org/ $10.3390 /$ ijms 22189763

Academic Editor: Raffaele Marfella

Received: 20 August 2021

Accepted: 7 September 2021

Published: 9 September 2021

Publisher's Note: MDPI stays neutral with regard to jurisdictional claims in published maps and institutional affiliations.

Copyright: (c) 2021 by the authors. Licensee MDPI, Basel, Switzerland. This article is an open access article distributed under the terms and conditions of the Creative Commons Attribution (CC BY) license (https:/ / creativecommons.org/licenses/by/ $4.0 /)$.

\begin{abstract}
Protein kinase C (PKC) activation can evoke vasoconstriction and contribute to coronary disease. However, it is unclear whether PKC activation, without activating the contractile machinery, can lead to coronary arteriolar dysfunction. The vasoconstriction induced by the PKC activator phorbol 12,13-dibutyrate (PDBu) was examined in isolated porcine coronary arterioles. The PDBu-evoked vasoconstriction was sensitive to a broad-spectrum PKC inhibitor but not affected by inhibiting PKC $\beta 2$ or Rho kinase. After exposure of the vessels to a sub-vasomotor concentration of PDBu $(1 \mathrm{nmol} / \mathrm{L}, 60 \mathrm{~min})$, the endothelium-dependent nitric oxide (NO)-mediated dilations in response to serotonin and adenosine were compromised but the dilation induced by the NO donor sodium nitroprusside was unaltered. PDBu elevated superoxide production, which was blocked by the superoxide scavenger Tempol. The impaired NO-mediated vasodilations were reversed by Tempol or inhibition of PKC $\beta 2$, xanthine oxidase, c-Jun N-terminal kinase (JNK) and Rho kinase but were not affected by a hydrogen peroxide scavenger or inhibitors of $\mathrm{NAD}(\mathrm{P}) \mathrm{H}$ oxidase and $\mathrm{p} 38$ kinase. The PKC $\beta 2$ protein was detected in the arteriolar wall and co-localized with endothelial NO synthase. In conclusion, activation of $P K C ~ \beta 2$ appears to compromise NO-mediated vasodilation via Rho kinase-mediated JNK signaling and superoxide production from xanthine oxidase, independent of the activation of the smooth muscle contractile machinery.
\end{abstract}

Keywords: oxidative stress; coronary disease; phorbol esters; nitric oxide; vasodilation; vasoconstriction; superoxide

\section{Introduction}

Protein kinase $\mathrm{C}(\mathrm{PKC})$ is a critical intracellular signaling molecule that orchestrates various vascular functions, including gene expression [1], cell differentiation [2] and proliferation [1], angiogenesis [3], permeability [4], vesicle trafficking [5], and vasoconstriction [6-11]. Cumulative evidence suggests a close relationship between PKC activation and production of reactive oxygen species (ROS) in vascular cells subjected to high pressure or hyperglycemic challenge [12]. Therefore, activation of PKC links to oxidative stress-associated vascular complications and blood flow dysregulation during disease development, including diabetes [13,14], ischemia-reperfusion injury [15], dyslipidemia [16], atherosclerosis [1], and hypertension [12]. Moreover, inhibition of PKC has been shown to attenuate vascular superoxide production in various forms of cardiovascular stress in animals $[14,17,18]$ and humans $[14,19]$. Interestingly, recent studies suggested a role of mitogen-activated protein kinases (MAPKs) or Rho kinase in superoxide production from coronary microvessels subjected to inflammatory insults [20-22] or harvested from animals with cardiovascular diseases $[21,23,24]$. However, it remains unclear whether 
direct activation of PKC signaling in the healthy vasculature can cause MAPK/Rho kinase activation and excessive superoxide production, with consequent vasomotor dysfunction.

It is well established that the vascular smooth muscle activity can be modulated by vasoactive substances released from the endothelium [25]. Numerous studies have shown that micromolar concentrations of phorbol 12,13-dibutyrate (PDBu), a direct PKC activator, evoke a sustained vasoconstriction in various tissues [7-11,26]. Interestingly, the endothelium-dependent vasodilation can be blunted by PDBu due to inhibition of synthesis/release and the action of nitric oxide (NO) [8]. These studies indicate that PKC activation not only elicits vasoconstriction but also compromises endothelial NO function. Therefore, the endothelial dysfunction is likely to accentuate the vasoconstriction following PKC activation. Alternatively, the vasoconstriction evoked by PKC can potentially mask endothelium-dependent vasorelaxation. Furthermore, the finding that the synthesis/release of endothelial vasodilators is influenced by the contractile activity of the underlying vascular smooth muscle cells $[27,28]$ adds another complexity to vasomotor regulation by PKC. Interestingly, the elevated smooth muscle $\mathrm{Ca}^{2+}$ during contraction can feedforward to the endothelium to evoke vasodilation [29]. This aforementioned crosstalk between smooth muscle and endothelial cells can confound interpretation of the endothelial effect of PKC in vasomotor regulation if the smooth muscle contractile machinery is also activated by the PKC. Therefore, the direct impact of PKC activation on endothelial NO function and the involved signaling molecules in association with oxidative stress remain unclear.

Herein, we directly addressed the impact of PKC activation by PDBu on endotheliumdependent NO-mediated dilation of isolated porcine coronary arterioles using a subvasomotor concentration of PDBu. The specific PKC isoform and the role of p38 kinase, c-Jun N-terminal kinase (JNK), and Rho kinase in oxidase activation and superoxide production were also determined in these microvessels, which are known to be responsible for coronary blood flow regulation [25,30].

\section{Results}

\subsection{Vasomotor Effect of PDBu and PKC Involvement}

To evaluate the vasomotor effect of $\mathrm{PDBu}$, the isolated coronary arterioles were exposed to cumulative concentrations of PDBu and the responses were recorded. Coronary arterioles (96 $\pm 5 \mu \mathrm{m}$ maximum diameter; $n=10)$ developed a stable basal tone $(67 \pm 2 \%$ of maximal diameter) and constricted in response to PDBu in a concentration-dependent manner (Figure 1A). PDBu at a $1 \mathrm{nmol} / \mathrm{L}$ concentration did not cause vasoconstriction but at $1 \mu \mathrm{mol} / \mathrm{L}$ it elicited a $50 \%$ reduction in the resting diameter (Figure $1 \mathrm{~A}$ ). The vasoconstriction caused by PDBu $(0.1 \mu \mathrm{mol} / \mathrm{L})$ was abolished by a pan-PKC inhibitor Gö6983 $(1 \mu \mathrm{mol} / \mathrm{L}, n=5)$ but was not affected by a PKC $\beta 2$ inhibitor CGP53353 $(0.3 \mu \mathrm{mol} / \mathrm{L}, n=5)$ or Rho kinase inhibitor Y27632 $(0.1 \mu \mathrm{mol} / \mathrm{L}, n=5)$ (Figure 1B).

In another series of experiments, the endothelium-dependent, NO-mediated vasodilations in response to serotonin $(0.1 \mathrm{nmol} / \mathrm{L}$ to $0.1 \mu \mathrm{mol} / \mathrm{L})$ and adenosine $(0.1 \mathrm{nmol} / \mathrm{L}$ to $10 \mu \mathrm{mol} / \mathrm{L}$ ) were examined before and after treating the vessel with a sub-threshold concentration $(1 \mathrm{nmol} / \mathrm{L})$ of PDBu for $60 \mathrm{~min}$. PDBu did not significantly alter the resting diameter of the vessels but inhibited the arteriolar dilations in response to serotonin (Figure 2A) and adenosine (Figure 2B). Addition of NO synthase (NOS) inhibitor L-NAME (10 $\mu \mathrm{mol} / \mathrm{L})$ did not affect the inhibitory effect of PDBu on vasodilations (Figure 2). Co-incubation of PDBu with a pan-PKC inhibitor Gö6983 or with PKC $\beta 2$ inhibitor CGP53353 prevented the inhibitory effect of PDBu (Figure 2). PDBu $(1 \mathrm{nmol} / \mathrm{L})$ had no effect on the vasodilation elicited by the NO donor sodium nitroprusside (Figure S1). 

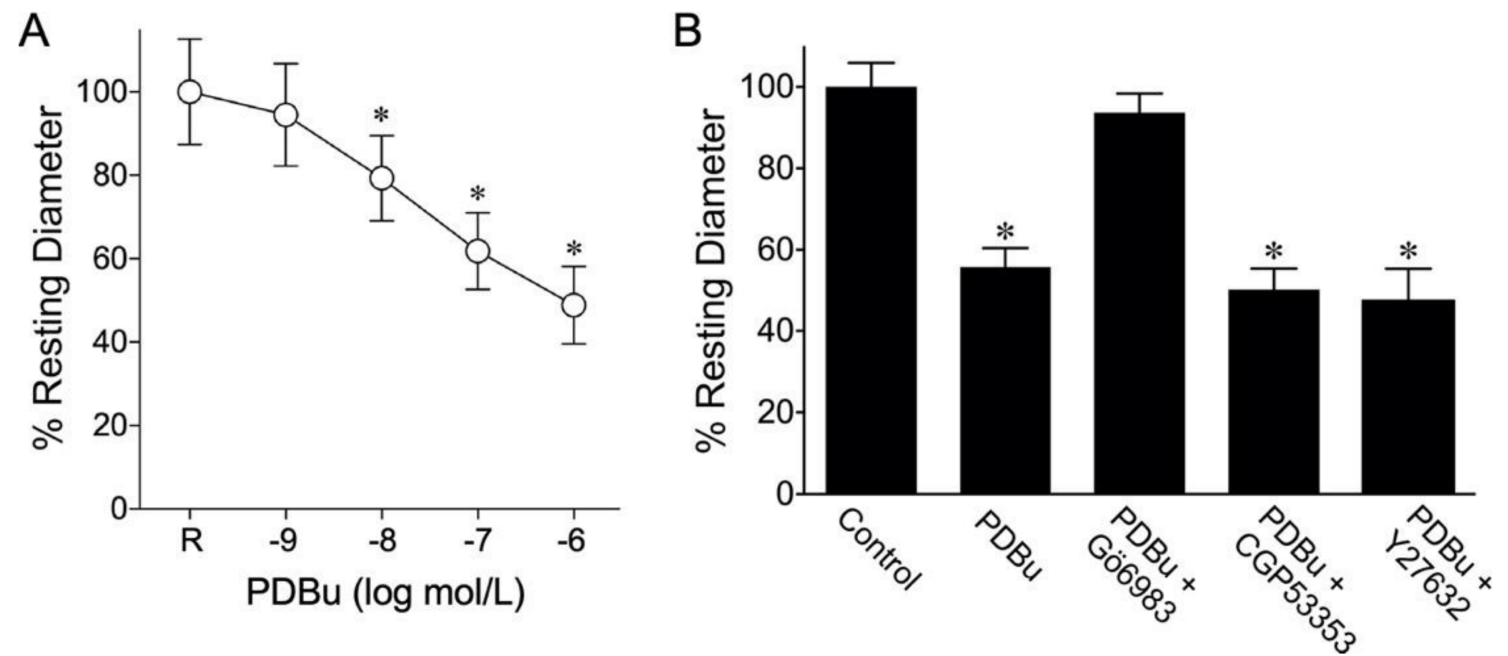

Figure 1. PDBu elicited concentration-dependent constriction of porcine coronary arterioles. (A) The low concentration of PDBu ( $1 \mathrm{nmol} / \mathrm{L})$ had no effect on vascular tone, but higher concentrations $(\geq 10 \mathrm{nmol} / \mathrm{L})$ caused significant vasoconstrictions $(n=6)$. ${ }^{*} p<0.05$ vs. resting diameter $(\mathrm{R})$, one-way repeated measures ANOVA with Dunnett's multiple comparison test. (B) PDBu-induced vasoconstriction (PDBu $0.1 \mu \mathrm{mol} / \mathrm{L}, n=5$ ) was prevented by the pan-PKC inhibitor Gö6983 (1 $\mu \mathrm{mol} / \mathrm{L}, n=5)$ but was not affected by the PKC $\beta 2$ inhibitor CGP53353 (0.3 $\mu \mathrm{mol} / \mathrm{L}, n=5)$ or Rho kinase inhibitor Y27632 $(0.1 \mu \mathrm{mol} / \mathrm{L}, n=5) .{ }^{*} p<0.05$ vs. the control, one-way ANOVA with Dunnett's multiple comparison test.
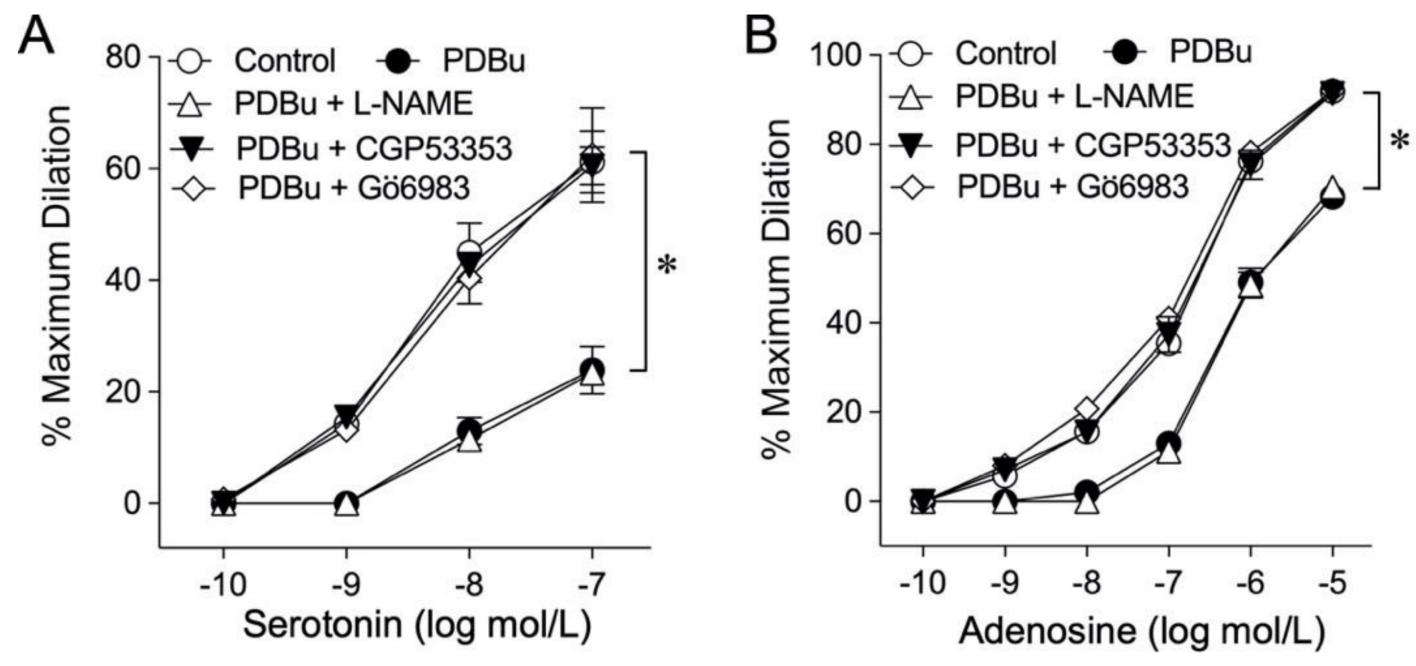

Figure 2. Impact of PKC activation on NO-mediated vasodilations to serotonin and adenosine. Vasodilations in response to serotonin (A) and adenosine (B) were inhibited by pre-treating the vessels with $1 \mathrm{nmol} / \mathrm{L} \mathrm{PDBu}$ for $60 \mathrm{~min}(n=6)$. The pan-PKC inhibitor Gö6983 ( $1 \mu \mathrm{mol} / \mathrm{L}, n=5)$ and PKC $\beta 2$ inhibitor CGP53353 (0.3 $\mu \mathrm{mol} / \mathrm{L}, n=5)$ prevented the PDBu-induced impairment of endothelium-dependent vasodilations. NOS inhibitor L-NAME $(10 \mu \mathrm{mol} / \mathrm{L}, n=4) \mathrm{did}$ not alter the inhibitory effect of PDBu. ${ }^{*} p<0.05$ vs. the control, two-way repeated measures ANOVA with Tukey's multiple comparison test.

2.2. Role of ROS, NAD $(P) H$ Oxidase, and Xanthine Oxidase in the PDBu-Induced Superoxide Production and Vascular Dysfunction

To determine whether ROS is involved in the attenuation of endothelium-dependent NO mediated vasodilation, vessels were treated with PDBu $(1 \mathrm{nmol} / \mathrm{L})$ in the presence of either the superoxide scavenger Tempol $(1 \mathrm{mmol} / \mathrm{L})$ or $\mathrm{H}_{2} \mathrm{O}_{2}$ scavenger PEG-catalase (500 U/mL). Pretreating the vessels with Tempol completely prevented the adverse effects of PDBu on vasodilations in response to serotonin (Figure 3A) and adenosine (Figure 3B). However, the cell-permeable $\mathrm{H}_{2} \mathrm{O}_{2}$ scavenger PEG-catalase had no effect on the inhibitory 
action of PDBu (Figure 3A,B). To determine whether NAD(P)H oxidase or xanthine oxidase contributes to the adverse effect of $\mathrm{PDBu}$, vessels were treated with $\mathrm{PDBu}$ in combination with inhibitor of $\mathrm{NAD}(\mathrm{P}) \mathrm{H}$ oxidase (apocynin, $100 \mu \mathrm{mol} / \mathrm{L}$ ) or of xanthine oxidase (allopurinol, $10 \mu \mathrm{mol} / \mathrm{L}$ ). In the presence of allopurinol, but not apocynin, the vasodilations to serotonin (Figure 3C) and adenosine (Figure 3D) were preserved. The vessels treated with PDBu significantly elevated the superoxide production in a manner sensitive to Tempol (Figure 4).
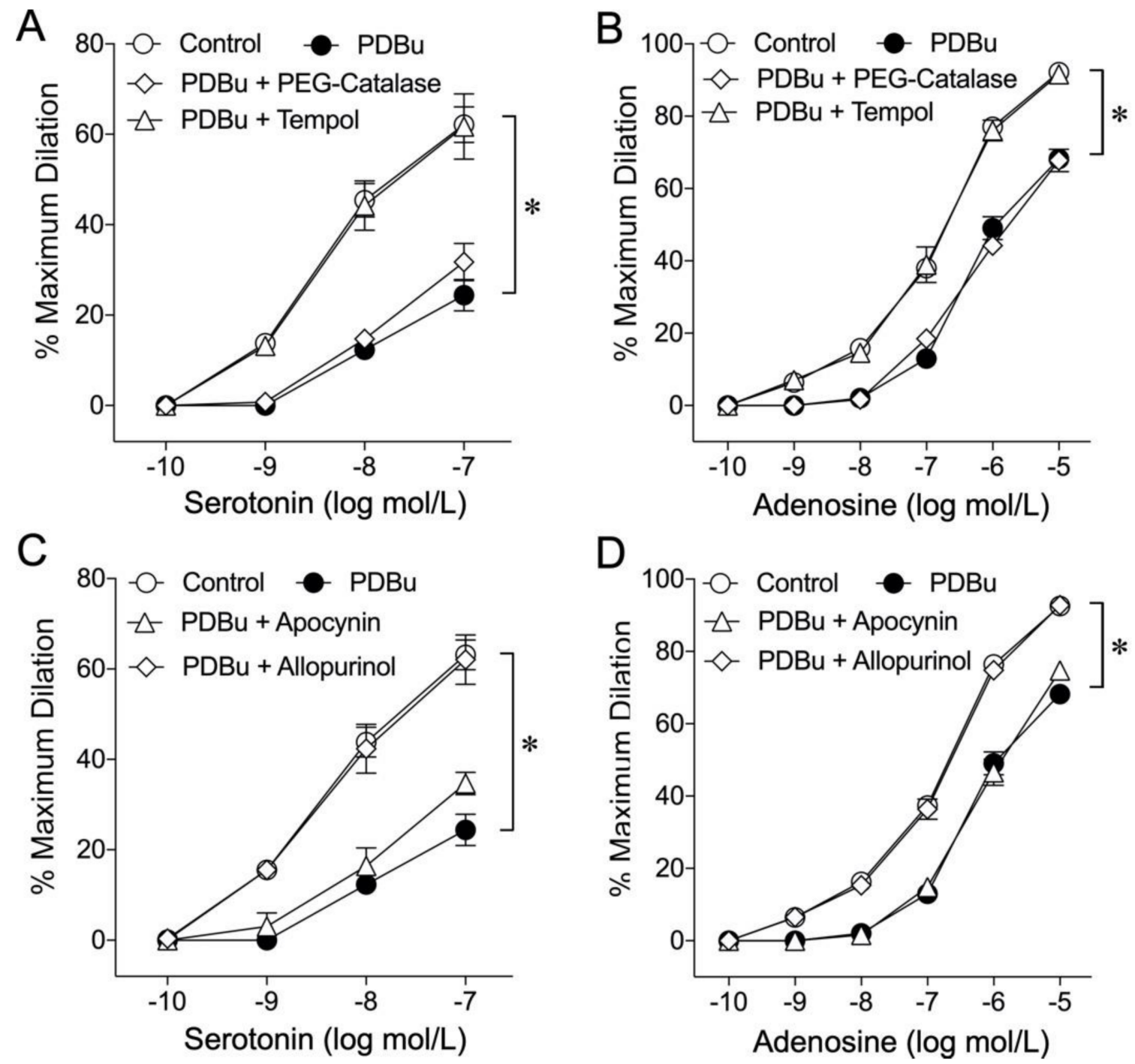

Figure 3. Role of oxidative stress in the adverse effect of PKC activation. The inhibitory effect of PDBu on vasodilations in response to serotonin (A) and adenosine (B) was prevented by pre-treating the vessels with the superoxide scavenger Tempol ( $1 \mathrm{mmol} / \mathrm{L}, n=5)$ but not by the cell permeable $\mathrm{H}_{2} \mathrm{O}_{2}$ scavenger PEG-catalase ( $\left.500 \mathrm{U} / \mathrm{mL}, n=5\right)$. The inhibitory effect of PDBu on vasodilations induced by serotonin (C) and adenosine (D) was prevented in vessels treated with the xanthine oxidase inhibitor allopurinol $(100 \mu \mathrm{mol} / \mathrm{L}, n=5)$. However, the $\mathrm{NAD}(\mathrm{P}) \mathrm{H}$ oxidase inhibitor apocynin $(100 \mu \mathrm{mol} / \mathrm{L}$, $n=5$ ) had no effect on PDBu-induced vascular impairment in response to serotonin (C) and adenosine (D). ${ }^{*} p<0.05$ vs. the control, two-way repeated measures ANOVA with Tukey's multiple comparison test. 

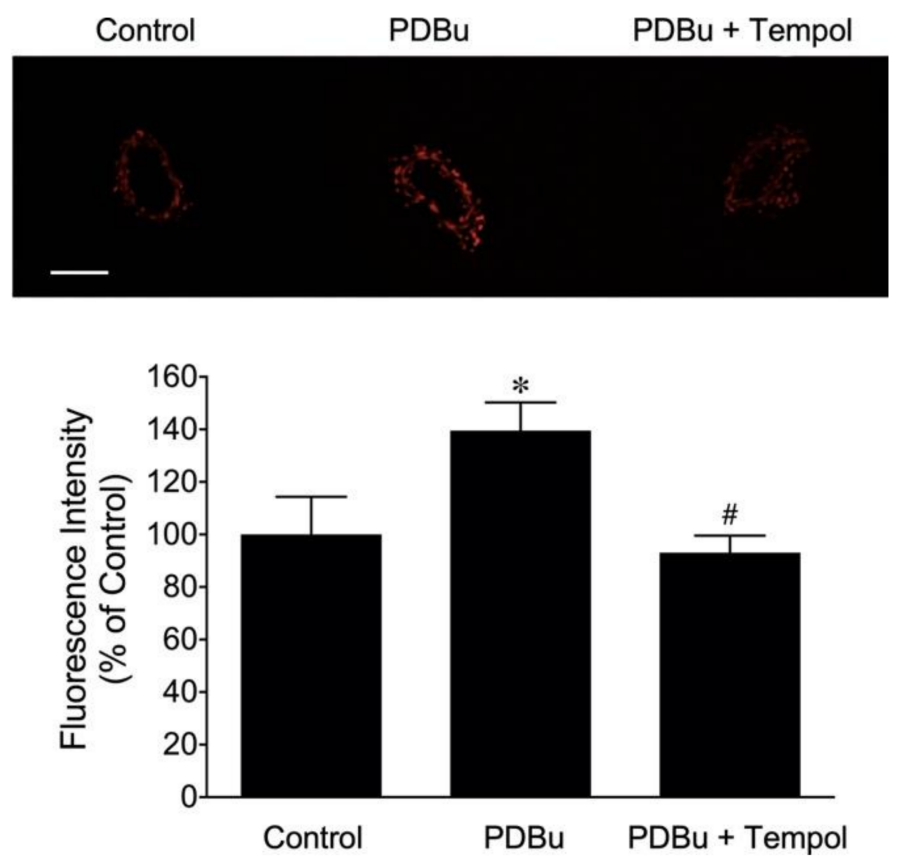

Figure 4. Detection of superoxide production in porcine coronary arterioles. Dihydroethidium (DHE) imaging of superoxide production in coronary arterioles after incubation of the vessels with PDBu $(1 \mathrm{nmol} / \mathrm{L}, 60 \mathrm{~min})$. PDBu markedly increased the superoxide level in the vascular wall, which was significantly reduced by co-incubation with the superoxide scavenger Tempol $(n=3)$. The result of the quantitative analysis of the DHE fluorescence signals is shown. Scale bar represents $100 \mu \mathrm{m}$. The data represent three independent experiments. ${ }^{*} p<0.05$ vs. the control, and $\# p<0.05 \mathrm{vs}$. PDBu treatment, Student's $t$-test.

\subsection{Expression of NOS and PKC $\beta 2$ in Coronary Arterioles}

To investigate the vascular expressions of endothelial NOS (eNOS) and PKC $\beta 2$, immunohistochemical detection of these two proteins was performed in isolated porcine coronary arterioles with a size comparable to that used for functional studies. The expression of PKC $\beta 2$ was found in both smooth muscle and endothelial cells and co-localized with eNOS in the endothelial layer (Figure 5).

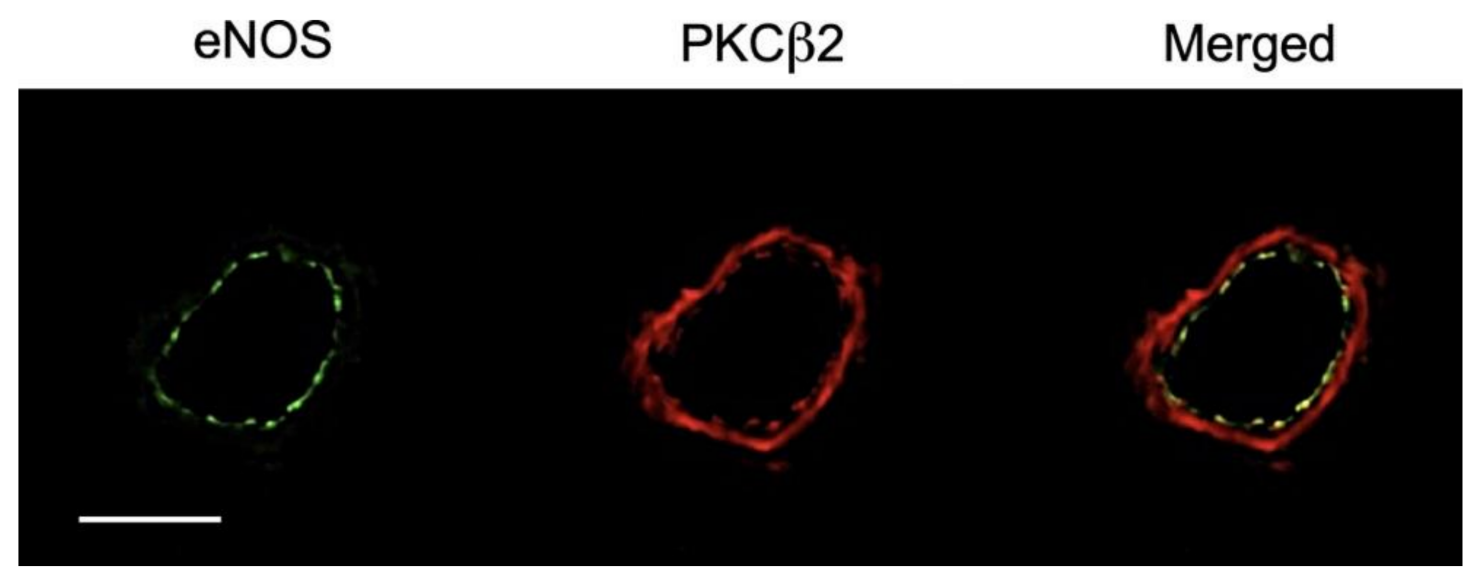

Figure 5. Immunohistochemical detection of endothelial NOS (eNOS) and PKC $\beta 2$ in porcine coronary arterioles. The expression of PKC $\beta 2$ (red) was found in smooth muscle and endothelial cells and co-localized with eNOS (green) in the endothelial layer (three independent experiments). Scale bar represents $50 \mu \mathrm{m}$. 


\subsection{Role of JNK, p38 Kinase, and Rho Kinase in the Inhibitory Effect of PDBu}

To investigate the involvement of JNK, p38 kinase, and Rho kinase in the adverse effect of $\mathrm{PDBu}$, the vasodilator responses were examined after treating the vessels with $\mathrm{PDBu}(1 \mathrm{nmol} / \mathrm{L})$ in the presence of the respective kinase inhibitor. The inhibitory effect of PDBu on vasodilations induced by serotonin (Figure 6A) and adenosine (Figure 6B) was prevented in the presence of the JNK inhibitor (SP600125, $5 \mu \mathrm{mol} / \mathrm{L}$ ) or Rho kinase inhibitor (Y-27632, $0.1 \mu \mathrm{mol} / \mathrm{L})$. However, the p38 kinase inhibitor (SB203580, $0.1 \mu \mathrm{mol} / \mathrm{L}$ ) had no effect on the action of PDBu (Figure 6).
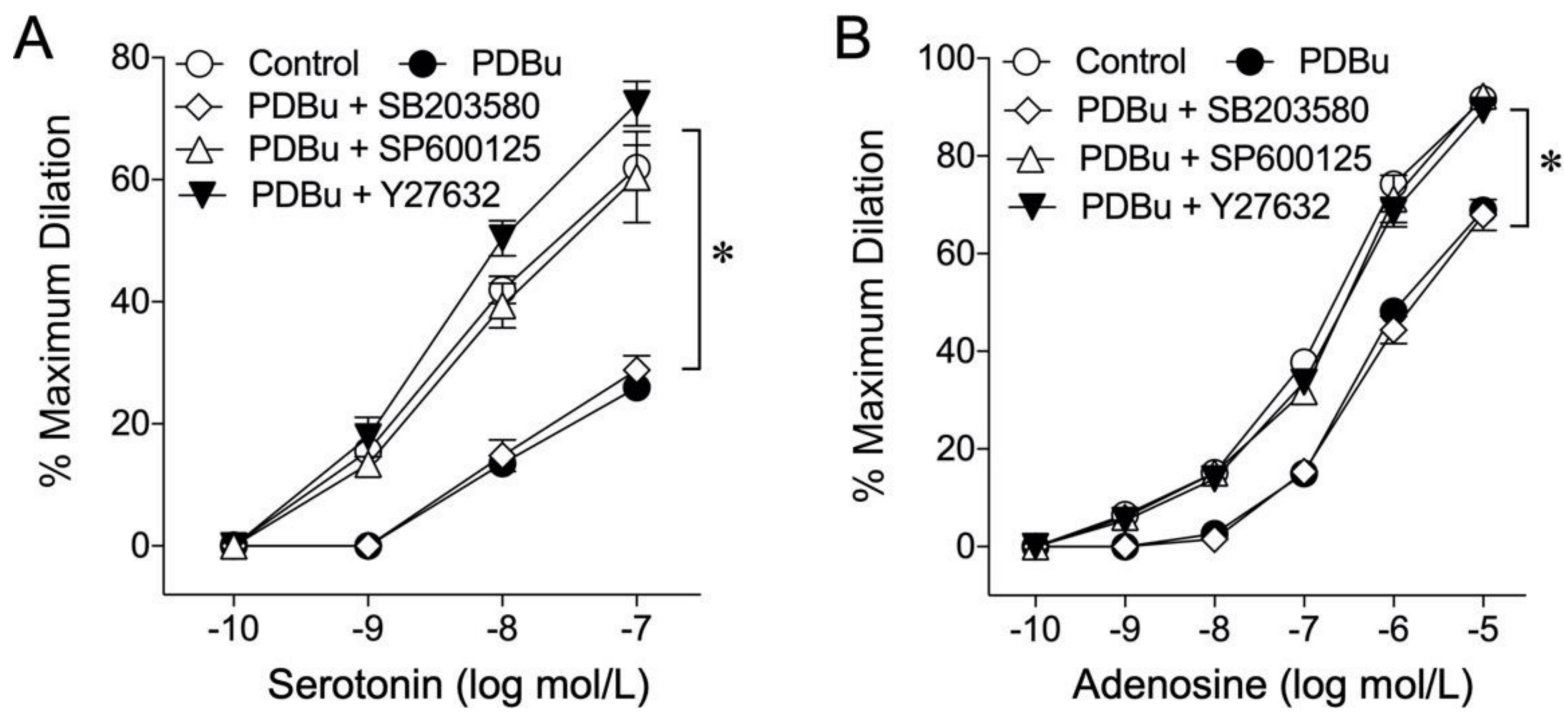

Figure 6. Role of kinases in the adverse effect of PKC activation. In the presence of the JNK inhibitor SP600125 (5 $\mu \mathrm{mol} / \mathrm{L}$, $n=5)$ or Rho kinase inhibitor Y-27632 $(0.1 \mu \mathrm{mol} / \mathrm{L}, n=5)$, but not p38 kinase inhibitor SB203580 $(0.1 \mu \mathrm{mol} / \mathrm{L}, n=5)$, the adverse effect of PDBu on vasodilations in response to serotonin (A) and adenosine (B) was prevented. ${ }^{*} p<0.05$ vs. the control, two-way repeated measures ANOVA with Tukey's multiple comparison test.

\section{Discussion}

PKC plays a central role in signal transduction for vasoconstriction and tissue inflammation and is thought to be involved in development of diabetes and atherosclerosis $[1,31]$ as well as other coronary diseases associated with endothelial dysfunction [32,33], which may underlie coronary vasospasm [34]. In the present study, activation of PKC by a subvasomotor concentration of PDBu elicits endothelial dysfunction by inhibiting endotheliumdependent, NO-mediated vasodilations (adenosine and serotonin) via elevated oxidative stress. The activation of xanthine oxidase by PKC $\beta 2$, linking to JNK and Rho kinase signalings, contributes to overt superoxide production and vascular dysfunction.

Although PKC was first identified as a $\mathrm{Ca}^{2+}$-activated phospholipid-dependent protein kinase, various isoforms were subsequently discovered and categorized into three subfamilies according to their structures and activators: conventional/classic (cPKCs), novel (nPKCs), and atypical (aPKCs). Activation of four $\mathrm{cPKCs}$ isoforms $(\alpha, \beta 1, \beta 2$, and $\gamma)$ requires $\mathrm{Ca}^{2+}$ and diacylglycerol (DAG), whereas the four $\mathrm{nPKC}$ isoforms $(\delta, \epsilon, \eta$, and $\theta)$ are activated by DAG alone [35]. The activation of aPKCs $(\iota / \lambda$, and $\zeta)$ is dependent upon phosphatidic acid and phosphatidylserine but not DAG or $\mathrm{Ca}^{2+}[36]$. In cPKC signaling, binding of $\mathrm{Ca}^{2+}$ increases the affinity of $\mathrm{cPKC}$ for membrane phosphatidylserine and promotes $\mathrm{CPKC}$ s binding to DAG at the cell membrane. Binding to DAG releases CPKC from autoinhibition, exposing the active site of $\mathrm{CPKC}$ for target phosphorylation. The pharmacological DAG analog, PDBu, acts in a similar manner to DAG to evoke PKC activation. It has been shown that micromolar concentrations of $\mathrm{PDBu}$ can cause vasoconstriction in various tissues via PKC activation [7-11,26]. Interestingly, in the swine model of coronary balloon injury, the PKC-mediated constrictions of coronary arteries to PDBu $(1 \mathrm{nmol} / \mathrm{kg}$ with 
estimated maximal concentration of $0.1 \mu \mathrm{mol} / \mathrm{L}$ ) or autacoids are significantly augmented in a $\mathrm{Ca}^{2+}$-dependent manner, in which the responses are blocked by the non-selective PKC inhibitor staurosporine [37]. This in vivo study suggests the involvement of cPKC activation in mediating the hyper-constriction, or vasospasm, of coronary arteries in the diseased state. However, the signaling mechanisms underlying the abnormal vascular reactivity remain unclear. It is possible that the diminished counteraction from the endothelial-released vasodilators due to balloon injury also contribute to or superimpose onto the enhanced vasoconstriction during PKC activation. It is unclear whether PKC activation, without evoking vasoconstriction, can cause endothelial dysfunction in healthy vessels.

In the present study, PDBu caused constriction of the coronary arterioles sensitive to the broad-spectrum PKC inhibitor (Gö6983) toward cPKCs, but not to the selective PKC $\beta 2$ inhibitor CGP53353 or Rho kinase inhibitor Y-27632 (Figure 1). These results excluded the involvement of PKC $\beta 2$ and Rho kinase in vasoconstriction to cPKC activation. In many cases, PKC has contraction-promoting effects, such as phosphorylation of plasma membrane channels/pumps to increase intracellular $\mathrm{Ca}^{2+}$ or phosphorylation of proteins that regulate cross-bridge cycling or $\mathrm{Ca}^{2+}$ sensitivity of contractile filaments in smooth muscle [26,38]. Similarly, Rho kinase can modulate vasomotor function by increasing $\mathrm{Ca}^{2+}$ sensitivity through inhibition of the myosin light chain phosphatase [26,38]. Interestingly, in the study of aortic vasomotor activity, the contraction elicited by PKC activation is sensitive to Rho kinase inhibitor, suggesting the interaction of these two signaling pathways $[9,10]$. The explanation for these inconsistent findings is unclear, but our results agree with previous studies in the microvasculature that Rho kinase plays no role in PKC-induced vasoconstriction [39]. It appears that the link of PKC activation to Rho kinase signaling for vasomotor control is mainly in conduit blood vessels $[9,10]$ in a manner consistent with an in vivo study showing the activation of PKC-mediated Rho kinase signaling in development of vasospasm in large coronary arteries under inflammatory insult [34]. On the other hand, the constriction of small resistance arteries to PKC activation seems to be independent of Rho kinase, suggesting the segmental disparity of vasculature in the involvement of Rho kinase signaling downstream from PKC activation [39]. It is worth noting that the concentrations of CGP53353 and Y-27638 used in the present study are adequate to inhibit PKC $\beta 2$ [40-42] and Rho kinase [43-47], respectively, as reported in various types of tissues.

The balance between smooth muscle tone and endothelial function in the microcirculation is essential for maintaining adequate tissue perfusion [25]. The endothelium plays an important role in blood flow regulation by controlling smooth muscle activity via released NO [30,48]. On the other hand, the increased smooth muscle tone can suppress endothelium-dependent NO-mediated dilation [49]. We have previously reported that both serotonin [50] and adenosine [51] cause endothelium-dependent NO-mediated dilation of porcine coronary arterioles through different signaling mechanisms. Interestingly, treating coronary arterioles with a sub-vasomotor concentration of PDBu $(1 \mathrm{nmol} / \mathrm{L})$ blunted vasodilations to both serotonin and adenosine (Figure 2). It appears that this effect is specifically related to the reduction of $\mathrm{NO}$ availability from the endothelium rather than the alteration of smooth muscle responsiveness to NO because inhibition of NOS in these PDBu-treated vessels did not further reduce the vasodilations (Figure 2) and the response of the vessels to the NO donor sodium nitroprusside remained unaltered (Figure S1). Moreover, our data suggest that PKC $\beta 2$ is involved in the development of endothelial dysfunction because application of its specific inhibitor prevented the adverse effect of PDBu. This finding is consistent with a previous study showing that PKC $\beta 2$ activation links to the impairment of flow-induced vasodilation in a microvascular network by suppression of $\mathrm{NO}$ release from the endothelium [52]. Interestingly, inhibition of PKC $\beta 2$ preserves endothelium-dependent vasodilation [53] and reverses endothelial barrier dysfunction [54] in experimental models with hyperglycemia and diabetes, which are known to cause endothelial NO deficiency $[14,23,52,55]$. It should be noted that PKC $\beta 2$ is expressed abundantly in the coronary arteriolar wall, including endothelial cells, and is 
co-localized with eNOS (Figure 5). In this regard, the observed endothelial dysfunction with compromised vasodilation in the present study is associated with activation of PKC $\beta 2$ without coupling to vasoconstriction. It appears that the induction of endothelial NO deficiency, compared to the initiation of smooth muscle contraction, is more sensitive to PKC activation in coronary arterioles.

Many cardiovascular diseases are associated with PKC activation [1,13-15], leading to elevated superoxide $[56-58]$ or hydrogen peroxide $[59,60]$ production. In the present study, the impaired NO-mediated vasodilation by a sub-vasomotor concentration of PDBu was prevented by the membrane-permeable superoxide scavenger Tempol, but not by the hydrogen peroxide scavenger PEG-catalase (Figure 3A,B), suggesting the specific contribution of superoxide to the adverse effect of PKC activation. This context is supported by the detection of an elevated superoxide level in the vascular wall after exposure to a sub-vasomotor concentration of PDBu (Figure 4). Tempol did not alter the resting vascular tone or vasodilator responses to serotonin, adenosine, and sodium nitroprusside [20] but preserved the endothelium-dependent vasodilations (Figure 3A,B) and reduced superoxide production in the PDBu-treated vascular wall (Figure 4). These data, in corroboration with the assessment of vascular function discussed above, support the role of elevated superoxide production in vascular dysfunction following PKC activation.

Activation of superoxide-producing enzymes, $\mathrm{NAD}(\mathrm{P}) \mathrm{H}$ oxidase and /or xanthine oxidase, has been shown to link to PKC activation $[11,14,56,58]$. Our results showed that allopurinol, but not apocynin, prevented the adverse effect of PDBu, indicating that xanthine oxidase was responsible for the superoxide production following PKC activation in coronary arterioles (Figure 3C,D). Interestingly, it has been reported that $\mathrm{NAD}(\mathrm{P}) \mathrm{H}$ oxidase is a source of oxidative stress in cultured vascular cells subjected to PKC activation by phorbol myristate acetate (PMA) or high glucose [61]. It is unclear whether the differences in the experimental model (cell culture vs. intact vessel) or the use of different PKC activators (PMA and high glucose vs. PDBu) between this and our study have contributed to the inconsistent results. Nevertheless, it has been shown that, in contrast to PDBu, superoxide production induced by PMA is not always associated with a change in cytosolic PKC activity [62]. It also cannot be excluded that the high concentration of PMA $(0.5 \mu \mathrm{M})$ used in the above cell culture study might also have triggered other signaling pathways for $\mathrm{NAD}(\mathrm{P}) \mathrm{H}$ oxidase activation. Our results are consistent with a previous study showing that the PKC-dependent xanthine oxidase-mediated superoxide production contributes to coronary endothelial dysfunction and NO deficiency in the heart perfused with inflammatory vasoconstrictor endothelin-1 or angiotensin-II [63]. Xanthine oxidase is also a major source of superoxide to compromise endothelial function and NO bioavailability in porcine [21] and murine [64] coronary arterioles subjected to inflammatory insults and in hypertensive/hypercholesterolemic patients exhibiting impaired coronary endothelium-dependent vasodilation [65]. Therefore, the mechanisms behind the observed functional inhibition by $\mathrm{PDBu}$ in the present study involved activation of $\mathrm{PKC} \beta 2$ and generation of superoxide, a direct NO scavenger, by xanthine oxidase.

Previous studies have shown that activation of various protein kinases, including Rho kinase and stress-activated protein kinases (p38 MAPK and JNK), can contribute to vasoconstrictor signaling $[24,66]$ or oxidative stress-associated vasomotor dysfunction $[20-22,67]$. Although the nanomolar concentration of PDBu employed in the present study was not sufficient to activate vasomotor activity, the responsible signaling kinase for PKC-induced endothelial dysfunction remained to be determined. In the present study, application of SP600125, but not SB203580, preserved vasodilations to serotonin and adenosine (Figure 6), indicating the involvement of JNK, rather than $\mathrm{p} 38$ kinase, in PKC $\beta 2$-mediated endothelial dysfunction. Interestingly, the impaired endothelium-dependent vasodilation by oxidative stress in coronary [22] and retinal [43] arterioles after C-reactive protein exposure is mediated by the activation of $\mathrm{p} 38$ kinase-dependent $\mathrm{NAD}(\mathrm{P}) \mathrm{H}$ oxidase. However, the role of PKC was not investigated in previous C-reactive protein studies. It appears that different stress environment triggers different signaling pathways, leading to vascular dysfunction. 
Nevertheless, our current study agrees with the study showing activation of JNK signaling and subsequent production of superoxide via xanthine oxidase under TNF $\alpha$-mediated inflammatory insult [21]. It is worth noting that TNF $\alpha$ can activate PKC $\beta 2$ and promotes oxidative stress in cultured human vascular endothelial cells [68], although the role of JNK in this in vitro study is unclear. Our present studies suggest that activation of PKC $\beta 2$, without confounding influence from the vasoconstrictor activity, can elicit oxidative stress via JNK-dependent xanthine oxidase activation and consequently compromise endothelial function in coronary arterioles.

Rho kinase activation has been shown to promote superoxide production and endothelial dysfunction in the porcine retinal [43,45] and coronary arterioles [24]. Inhibition of Rho kinase increases vascular NO production $[69,70]$ and improves endothelial function in various vascular diseases, in which augmented vasoconstriction is commonly observed $[24,65,70,71]$. In the present study, we found that a Rho kinase inhibitor preserved coronary arteriolar dilations to serotonin and adenosine (Figure 6) but failed to block vasoconstriction in response to PKC activation (Figure 1B). These results indicate that Rho kinase is not involved in the vasoconstriction evoked by PKC but mediates the signaling to oxidative stress and endothelial dysfunction. The activation of $P K C \beta 2$, as suggested by the present study, appears to promote vascular superoxide production from xanthine oxidase through Rho kinase and JNK activations (Figure 7). It is noted that both Rho kinase and JNK inhibitors exhibited the same efficacy in preserving vasomotor function (Figure 6), suggesting their action on the same signaling pathway. Although the signaling sequence between Rho kinase and JNK in the present study remains unclear, it has been shown that JNK activity can be regulated by Rho kinase in various cell types, including vascular cells [72,73]. Recently, the activation of JNK by Rho kinase has been suggested to mediate enhanced venular constriction to endothelin-1 in diabetic animals [66]. The sequential activation of Rho kinase and JNK for endothelial dysfunction following PKC $\beta 2$ activation deserves further investigation.

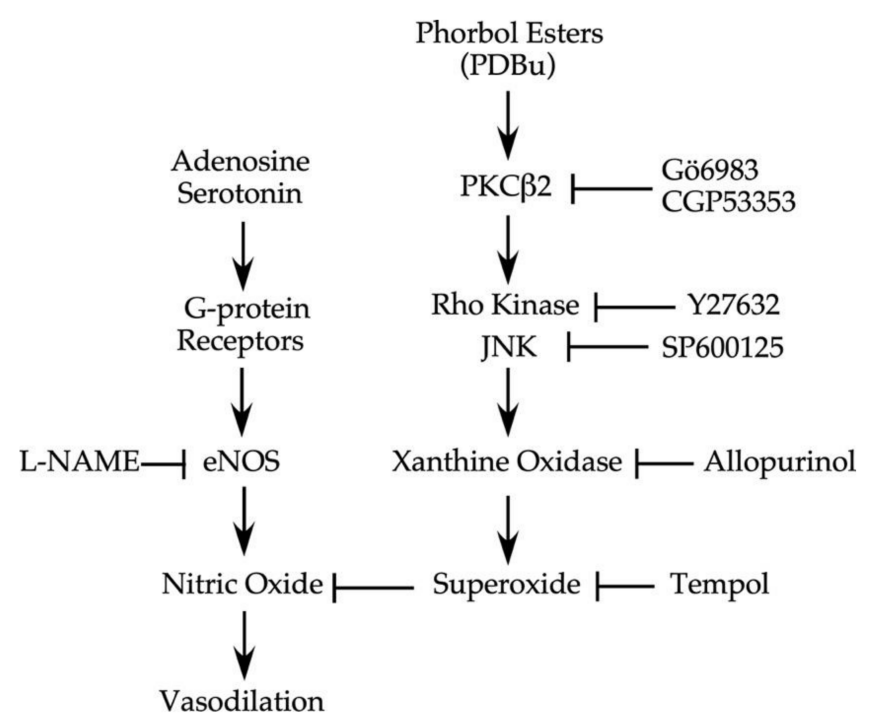

Figure 7. The diagram summarizes the pathways involved in endothelial dysfunction elicited by PDBu. Both serotonin and adenosine activate their G-protein coupled receptors and elicit endothelium-dependent nitric oxide (NO)-mediated vasodilation via endothelial NO synthase (eNOS). Activation of PKC by a nanomolar concentration of PDBu has a minimal effect on vascular tone but compromises NO-mediated vasodilations in response to adenosine and serotonin due to increased superoxide production. The signaling events through Rho kinase and JNK act in concert following PKC $\beta 2$ activation to promote superoxide production from xanthine oxidase and consequently lead to NO deficiency. The inhibitors used in the present study to probe the involved signaling molecules are indicated. 
In summary, the present study demonstrated that activation of PKC by PDBu elicits at least two different pathways, one leads to Rho kinase-independent vasoconstriction, and the other leads to Rho kinase-dependent superoxide production and impairment of endothelium-dependent NO-mediated dilation in porcine coronary arterioles. Selective activation of $\mathrm{PKC} \beta 2$, by a sub-vasomotor concentration of $\mathrm{PDBu}$, appears to trigger JNK-dependent activation of xanthine oxidase for superoxide production via Rho kinase signaling (Figure 7). It appears that elevated basal production of superoxide without activation of smooth muscle contractile machinery is sufficient to evoke endothelial dysfunction. Because PKC is an important regulator for vascular smooth muscle function and a pathological target in vascular disorders [74], understanding the direct role of PKC activation in the intact vessel could advance the design of therapeutic tools for disease prevention and treatment.

\section{Materials and Methods}

\subsection{Materials}

The animal procedures and protocols were carried out under the guidance of the Animal Care and Use Committee (ID: 2007-008-R approved on February 16, 2010) at the Texas A\&M University Health Science Center and Baylor Scott \& White Health (Temple, TX, USA). Pigs (8-12 weeks old, either sex) were purchased from Real Farms (San Antonio, TX, USA) and sedated with Telazol (4-8 $\mathrm{mg} / \mathrm{kg}$, intramuscularly), anesthetized with $2-5 \%$ isoflurane (Baxter Healthcare Co., Deerfield, IL, USA), heparinized with heparin (1000 U/kg, intravenously via marginal ear vein; Cardinal Health, Dublin, OH, USA), and intubated. A left lateral thoracotomy was performed, and the heart was swiftly removed and immersed in cold $\left(5^{\circ} \mathrm{C}\right)$ saline solution as previously described $[75,76]$.

\subsection{Isolation and Cannulation of Coronary Microvessels}

To eliminate the confounding influences from hemodynamic, neurohumoral, and myocardial metabolic changes, coronary arterioles were isolated and studied ex vivo [77]. Subepicardial coronary arterioles $(40-80 \mu \mathrm{m}$ internal diameter in situ) were carefully dissected out and cannulated with a pair of glass micropipettes in a vessel chamber containing physiological salt solution (PSS) and $1 \%$ bovine serum albumin (Thermo Fisher Scientific, Bridgewater, NJ, USA) [49]. The isolated vessels were pressurized to $60 \mathrm{cmH}_{2} \mathrm{O}$ intraluminal pressure, based on the reported level of pressure distribution in vivo [78], by two independent reservoirs [77]. The vessels developed a basal tone within $40 \mathrm{~min}$ at a $37^{\circ} \mathrm{C}$ bath temperature. The internal diameters of the arterioles were recorded throughout the experiment using videomicroscopic techniques [49].

\subsection{Effect of PDBu on Vasodilator Function of Isolated Coronary Arterioles}

After development of a stable resting diameter (i.e., basal tone), the concentrationdependent vasoconstriction of coronary arterioles to PDBu was constructed and the involvements of PKC subtypes and Rho kinase were assessed with inhibitor Gö6983 $(1 \mu \mathrm{mol} / \mathrm{L})$ [79] against a broad-spectrum of PKC (PKC $\alpha, \mathrm{PKC} \beta, \mathrm{PKC} \gamma, \mathrm{PKC} \delta$ and PKC $\zeta)$, CGP53353 (0.3 $\mu \mathrm{mol} / \mathrm{L})$ against PKC $\beta 2$ [42,80], and Y27632 (0.1 $\mu \mathrm{mol} / \mathrm{L}$; Calbiochem, San Diego, CA, USA) against Rho kinase [20]. In another series of experiments, coronary arterioles were exposed to a sub-vasomotor level of PDBu $(1 \mathrm{nmol} / \mathrm{L})$ for $60 \mathrm{~min}$ and the vessels were challenged with the endothelium-dependent, $\mathrm{NO}$-mediated vasodilators serotonin $(0.1 \mathrm{nmol} / \mathrm{L}$ to $0.1 \mu \mathrm{mol} / \mathrm{L})$ and adenosine $(0.1 \mathrm{nmol} / \mathrm{L}$ to $10 \mu \mathrm{mol} / \mathrm{L})$ and the endotheliumindependent vasodilator sodium nitroprusside $(0.1 \mathrm{nmol} / \mathrm{L}$ to $10 \mu \mathrm{mol} / \mathrm{L})$. To examine the contribution of superoxide and hydrogen peroxide to the sub-vasomotor effect of PDBu, the vasodilations to serotonin and adenosine were assessed before and after co-incubation of $\mathrm{PDBu}$ with superoxide scavenger 4-hydroxy-2,2,6,6-tetramethylpiperidine-1-oxyl (Tempol, $1 \mathrm{mmol} / \mathrm{L})$ [55] and hydrogen peroxide scavenger PEG-catalase (500 U/mL) [81], respectively. The roles of $\mathrm{NAD}(\mathrm{P}) \mathrm{H}$ oxidase and xanthine oxidase were determined in the presence of their respective inhibitors apocynin $(100 \mu \mathrm{mol} / \mathrm{L})$ and allopurinol $(10 \mu \mathrm{mol} / \mathrm{L})$ [20]. In 
another series of studies, the involved PKC subtypes, NO, and stress-activated protein kinases were examined by co-treating the vessels with a sub-vasomotor concentration of PDBu and inhibitors of pan-PKC (Gö6983, $1 \mu \mathrm{mol} / \mathrm{L})$, PKC $\beta 2$ (CGP53353, $0.3 \mu \mathrm{mol} / \mathrm{L})$,

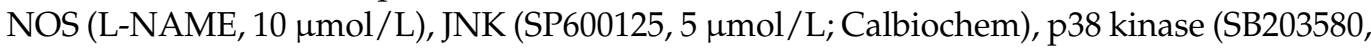
$0.1 \mu \mathrm{mol} / \mathrm{L}$; Calbiochem), or Rho kinase (Y27632, $0.1 \mu \mathrm{mol} / \mathrm{L})$. The concentrations of inhibitors used in the present study have been shown to be effective in microvessel preparations [20,22,55,79,81,82]. In each pharmacological intervention, 4 to 6 arterioles were used. All drugs, unless otherwise stated, were obtained from Sigma-Aldrich (St. Louis, MO, USA).

\subsection{Immunohistochemical Detection of eNOS and PKC $\beta 2$}

Coronary arterioles were embedded in OCT compound (Tissue-Tek; Electron Microscopy Sciences, Hatfield, PA, USA) and frozen sections (10 $\mu \mathrm{m}$ thickness) were fixed in $4 \%$ paraformaldehyde for immunohistochemical analysis as described previously $[83,84]$. Immunolabelling was performed using a mouse monoclonal antibody against eNOS (610297, 1:100 dilution; BD Biosciences, Franklin Lakes, NJ, USA) and a rabbit polyclonal antibody against PKC $\beta 2$ (sc-210, 1:100 dilution; Santa Cruz Biotechnology, Dallas, TX, USA). The slides were then incubated with rhodamine red-labeled (Jackson Laboratories, West Grove, PA, USA) and FITC-labeled (Jackson Laboratories) secondary antibodies. Staining control tissues were exposed for the same duration to non-immune serum (Jackson Laboratories) in place of primary antibody. Slides were observed for red (rhodamine red for PKC $\beta 2$ ) and green (FITC for eNOS) images under a fluorescence microscope (Axiovert 200, Zeiss, Jena, Germany) and analyzed using ImageJ software (National Institutes of Health, Bethesda, MD, USA) as described previously [20].

\subsection{Detection of Vascular Superoxide}

Superoxide production in isolated coronary arterioles was evaluated with the fluorescent dye dihydroethidium (DHE; Polysciences, Warrington, PA, USA) as described previously [20]. Isolated coronary arterioles, 40 to $100 \mu \mathrm{m}$ in diameter and $1.5 \mathrm{~mm}$ in length, were incubated with a vehicle solution, PDBu $(1 \mathrm{nmol} / \mathrm{L})$, or PDBu plus Tempol $(1 \mathrm{mmol} / \mathrm{L})$, and then stained with DHE $(4 \mu \mathrm{mol} / \mathrm{L})$ for $30 \mathrm{~min}$. After being washed, arterioles were embedded in OCT compound (Tissue-Tek) for frozen section (10 $\mu \mathrm{m}$ thickness). The DHE fluorescence image was taken at excitation/emission wavelength of 360/460 nm with a fluorescence microscope (Axiovert 200, Zeiss). Control and experimental tissues were set on the same slide and processed and analyzed under the same conditions.

\subsection{Data Analysis}

Vasoconstriction to PDBu was normalized to the resting vessel diameter following development of vascular tone [20]. Arteriolar responses to vasodilators were normalized to the maximal diameter obtained in the $\mathrm{Ca}^{2+}$-free solution containing $0.1 \mathrm{mmol} / \mathrm{L}$ sodium nitroprusside and are expressed as a percentage of the maximal dilation [51]. Data are reported as the mean \pm SEM, and " $n$ " represents the number of vessels (1-2 vessels per pig). The changes in resting tone by PDBu and pharmacological inhibitors were analyzed with one-way analysis of variance (ANOVA) followed by a Dunnett's multiple comparison test. The fluorescence images from DHE staining were quantified using ImageJ software as previously described [22] and then analyzed with a Student's $t$-test. The significance of the experimental interventions on vasomotor responses to serotonin and adenosine was analyzed with a two-way ANOVA followed by Tukey's multiple comparison test. A value of $p<0.05$ was considered statistically significant.

Supplementary Materials: The following are available online at https:/ /www.mdpi.com/article/10 $.3390 /$ ijms22189763/s1.

Author Contributions: Conceptualization, N.T., T.W.H. and L.K.; conducting experiments, N.T. and Y.R.; methodology, N.T., T.W.H. and L.K.; data analysis, N.T., L.K. and T.W.H.; writing-original draft 
preparation, N.T.; writing-review and editing, N.T., T.W.H. and L.K.; immunohistological analysis, Y.R.; funding acquisition, L.K., T.W.H. and N.T. All authors have read and agreed to the published version of the manuscript.

Funding: This work was supported by the Scott \& White Hospital Kruse Endowment Fund to L.K., NIH R01EY018420 to T.W.H., and by the Office of the Ministry of Higher Education, Science, Research and Innovation and the Thailand Science Research and Innovation through the Kasetsart University Reinventing Program 2021 to N.T.

Institutional Review Board Statement: The experimental procedures and protocols were carried out under the guidance of the Animal Care and Use Committee (ID: 2007-008-R approved on February 16, 2010) at the Texas A\&M University Health Science Center and Baylor Scott \& White Health.

Informed Consent Statement: Not applicable.

Data Availability Statement: The datasets generated and/or analyzed for the current study are available from the corresponding authors upon reasonable request.

Acknowledgments: The authors gratefully acknowledge Wenjuan $\mathrm{Xu}$ and $\mathrm{Xin} \mathrm{Xu}$ for their technical support and assistance in the collection of heart samples.

Conflicts of Interest: All authors declare that they have no conflict of interests. The funders had no role in the design of the study; in the collection, analyses, or interpretation of data; in the writing of the manuscript, or in the decision to publish the results.

\section{References}

1. Rask-Madsen, C.; King, G.L. Proatherosclerotic mechanisms involving protein kinase C in diabetes and insulin resistance. Arterioscler. Thromb. Vasc. Biol. 2005, 25, 487-496. [CrossRef] [PubMed]

2. Ishisaki, A.; Tsunobuchi, H.; Nakajima, K.; Imamura, T. Possible involvement of protein kinase C activation in differentiation of human umbilical vein endothelium-derived cell into smooth muscle-like cell. Biol. Cell 2004, 96, 499-508. [CrossRef] [PubMed]

3. Andrikopoulos, P.; Baba, A.; Matsuda, T.; Djamgoz, M.B.; Yaqoob, M.M.; Eccles, S.A. $\mathrm{Ca}^{2+}$ influx through reverse mode $\mathrm{Na}^{+} / \mathrm{Ca}^{2+}$ exchange is critical for vascular endothelial growth factor-mediated extracellular signal-regulated kinase (ERK) $1 / 2$ activation and angiogenic functions of human endothelial cells. J. Biol. Chem. 2011, 286, 37919-37931. [CrossRef]

4. Tiruppathi, C.; Minshall, R.D.; Paria, B.C.; Vogel, S.M.; Malik, A.B. Role of $\mathrm{Ca}^{2+}$ signaling in the regulation of endothelial permeability. Vasc. Pharmacol. 2002, 39, 173-185. [CrossRef]

5. Muro, S.; Mateescu, M.; Gajewski, C.; Robinson, M.; Muzykantov, V.R.; Koval, M. Control of intracellular trafficking of ICAM-1targeted nanocarriers by endothelial $\mathrm{Na}^{+} / \mathrm{H}^{+}$exchanger proteins. Am. J. Physiol. Lung Cell. Mol. Physiol. 2006, 290, L809-L817. [CrossRef]

6. Chen, Y.L.; Ren, Y.; Xu, W.; Rosa, R.H., Jr.; Kuo, L.; Hein, T.W. Constriction of retinal venules to endothelin-1: Obligatory roles of $\mathrm{ET}_{\mathrm{A}}$ receptors, extracellular calcium entry, and rho kinase. Investig. Ophthalmol. Vis. Sci. 2018, 59, 5167-5175. [CrossRef]

7. Potts, L.B.; Bradley, P.D.; Xu, W.; Kuo, L.; Hein, T.W. Role of endothelium in vasomotor responses to endothelin system and protein kinase C activation in porcine retinal arterioles. Investig. Ophthalmol. Vis. Sci. 2013, 54, 7587-7594. [CrossRef]

8. Rubanyi, G.M.; Desiderio, D.; Luisi, A.; Johns, A.; Sybertz, E.J. Phorbol dibutyrate inhibits release and action of endotheliumderived relaxing factor(s) in canine blood vessels. J. Pharmacol. Exp. Ther. 1989, 249, 858-863.

9. Shimomura, E.; Shiraishi, M.; Iwanaga, T.; Seto, M.; Sasaki, Y.; Ikeda, M.; Ito, K. Inhibition of protein kinase C-mediated contraction by Rho kinase inhibitor fasudil in rabbit aorta. Naunyn-Schmiedeberg Arch. Pharmacol. 2004, 370, 414-422. [CrossRef]

10. Baek, I.; Jeon, S.B.; Kim, J.; Seok, Y.M.; Song, M.J.; Chae, S.C.; Jun, J.E.; Park, W.H.; Kim, I.K. A role for Rho-kinase in Ca ${ }^{2+}$ independent contractions induced by phorbol-12,13-dibutyrate. Clin. Exp. Pharmacol. Physiol. 2009, 36, 256-261. [CrossRef]

11. Gupte, S.A.; Kaminski, P.M.; George, S.; Kouznestova, L.; Olson, S.C.; Mathew, R.; Hintze, T.H.; Wolin, M.S. Peroxide generation by 47 phox-Src activation of Nox2 has a key role in protein kinase C-induced arterial smooth muscle contraction. Am. J. Physiol. Heart Circ. Physiol. 2009, 296, H1048-H1057. [CrossRef]

12. Yasunari, K.; Maeda, K.; Nakamura, M.; Yoshikawa, J. Carvedilol inhibits pressure-induced increase in oxidative stress in coronary smooth muscle cells. Hypertens. Res. 2002, 25, 419-425. [CrossRef] [PubMed]

13. Kang, N.; Alexander, G.; Park, J.K.; Maasch, C.; Buchwalow, I.; Luft, F.C.; Haller, H. Differential expression of protein kinase C isoforms in streptozotocin-induced diabetic rats. Kidney Int. 1999, 56, 1737-1750. [CrossRef]

14. Gutterman, D.D. Vascular dysfunction in hyperglycemia: Is protein kinase C the culprit? Circ. Res. 2002, 90, 5-7. [CrossRef]

15. Hoshino, S.; Kikuchi, Y.; Nakajima, M.; Kimura, H.; Tsuyama, S.; Uemura, K.; Yoshida, K. Endothelial NO Synthase (eNOS) phosphorylation regulates coronary diameter during ischemia-reperfusion in association with oxidative stress. Free Radic. Res. 2005, 39, 481-489. [CrossRef]

16. Korzick, D.H.; Rishel, M.E.; Bowles, D.K. Exercise and hypercholesterolemia produce disparate shifts in coronary PKC expression. Med. Sci. Sports Exerc. 2005, 37, 381-388. [CrossRef] 
17. Maczewski, M.; Beresewicz, A. The role of endothelin, protein kinase $C$ and free radicals in the mechanism of the post-ischemic endothelial dysfunction in guinea-pig hearts. J. Mol. Cell. Cardiol. 2000, 32, 297-310. [CrossRef] [PubMed]

18. Ungvari, Z.; Csiszar, A.; Huang, A.; Kaminski, P.M.; Wolin, M.S.; Koller, A. High pressure induces superoxide production in isolated arteries via protein kinase C-dependent activation of NAD(P)H oxidase. Circulation 2003, 108, 1253-1258. [CrossRef] [PubMed]

19. Touyz, R.M.; Schiffrin, E.L. Increased generation of superoxide by angiotensin II in smooth muscle cells from resistance arteries of hypertensive patients: Role of phospholipase D-dependent NAD(P)H oxidase-sensitive pathways. J. Hypertens. 2001, 19, 1245-1254. [CrossRef]

20. Thengchaisri, N.; Hein, T.W.; Ren, Y.; Kuo, L. Endothelin-1 impairs coronary arteriolar dilation: Role of p38 kinase-mediated superoxide production from NADPH oxidase. J. Mol. Cell. Cardiol. 2015, 86, 75-84. [CrossRef]

21. Zhang, C.; Hein, T.W.; Wang, W.; Ren, Y.; Shipley, R.D.; Kuo, L. Activation of JNK and xanthine oxidase by TNF- $\alpha$ impairs nitric oxide-mediated dilation of coronary arterioles. J. Mol. Cell. Cardiol. 2006, 40, 247-257. [CrossRef]

22. Qamirani, E.; Ren, Y.; Kuo, L.; Hein, T.W. C-reactive protein inhibits endothelium-dependent NO-mediated dilation in coronary arterioles by activating $\mathrm{p} 38$ kinase and NAD(P)H oxidase. Arterioscler. Thromb. Vasc. Biol. 2005, 25, 995-1001. [CrossRef]

23. Hein, T.W.; Xu, X.; Ren, Y.; Xu, W.; Tsai, S.H.; Thengchaisri, N.; Kuo, L. Requisite roles of LOX-1, JNK, and arginase in diabetes-induced endothelial vasodilator dysfunction of porcine coronary arterioles. J. Mol. Cell. Cardiol. 2019, 131, 82-90. [CrossRef]

24. Tsai, S.H.; Lu, G.; Xu, X.; Ren, Y.; Hein, T.W.; Kuo, L. Enhanced endothelin-1/Rho-kinase signalling and coronary microvascular dysfunction in hypertensive myocardial hypertrophy. Cardiovasc. Res. 2017, 113, 1329-1337. [CrossRef] [PubMed]

25. Davis, M.J.; Hill, M.; Kuo, L. Local Regulation of Microvascular Perfusion. In Handbook of Physiology, Section 2: The Cardiovascular System. Microcirculation, 2nd ed.; Pt. 2, Chpt. 6; Tuma, R.F., Duran, W.N., Ley, K., Eds.; American Physiological Society: Maryland, MD, USA, 2008; pp. 161-284. [CrossRef]

26. Fu, X.; Gong, M.C.; Jia, T.; Somlyo, A.V.; Somlyo, A.P. The effects of the Rho-kinase inhibitor Y-27632 on arachidonic acid-, GTPgammaS-, and phorbol ester-induced $\mathrm{Ca}^{2+}$-sensitization of smooth muscle. FEBS Lett. 1998, 440, 183-187. [CrossRef]

27. Allen, T.; Iftinca, M.; Cole, W.C.; Plane, F. Smooth muscle membrane potential modulates endothelium-dependent relaxation of rat basilar artery via myo-endothelial gap junctions. J. Physiol. 2002, 545, 975-986. [CrossRef] [PubMed]

28. Kerr, P.M.; Tam, R.; Ondrusova, K.; Mittal, R.; Narang, D.; Tran, C.H.; Welsh, D.G.; Plane, F. Endothelial feedback and the myoendothelial projection. Microcirculation 2012, 19, 416-422. [CrossRef] [PubMed]

29. Garland, C.J.; Bagher, P.; Powell, C.; Ye, X.; Lemmey, H.A.L.; Borysova, L.; Dora, K.A. Voltage-dependent Ca ${ }^{2+}$ entry into smooth muscle during contraction promotes endothelium-mediated feedback vasodilation in arterioles. Sci. Signal. 2017, 10, 486. [CrossRef] [PubMed]

30. Chilian, W.M.; Kuo, L.; DeFily, D.V.; Jones, C.J.; Davis, M.J. Endothelial regulation of coronary microvascular tone under physiological and pathophysiological conditions. Eur. Heart J. 1993, 14 (Suppl. I), 55-59.

31. Poznyak, A.; Grechko, A.V.; Poggio, P.; Myasoedova, V.A.; Alfieri, V.; Orekhov, A.N. The diabetes mellitus-atherosclerosis connection: The role of lipid and glucose metabolism and chronic inflammation. Int. J. Mol. Sci. 2020, 21, 1835. [CrossRef] [PubMed]

32. Tinsley, J.H.; Hunter, F.A.; Childs, E.W. PKC and MLCK-dependent, cytokine-induced rat coronary endothelial dysfunction. J. Surg. Res. 2009, 152, 76-83. [CrossRef]

33. Giardina, J.B.; Tanner, D.J.; Khalil, R.A. Oxidized-LDL enhances coronary vasoconstriction by increasing the activity of protein kinase $\mathrm{C}$ isoforms alpha and epsilon. Hypertension 2001, 37, 561-568. [CrossRef] [PubMed]

34. Kandabashi, T.; Shimokawa, H.; Miyata, K.; Kunihiro, I.; Eto, Y.; Morishige, K.; Matsumoto, Y.; Obara, K.; Nakayama, K.; Takahashi, S.; et al. Evidence for protein kinase C-mediated activation of Rho-kinase in a porcine model of coronary artery spasm. Arterioscler. Thromb. Vasc. Biol. 2003, 23, 2209-2214. [CrossRef]

35. Khalil, R.A. Protein kinase $C$ inhibitors as modulators of vascular function and their application in vascular disease. Pharmaceuticals 2013, 6, 407-439. [CrossRef]

36. Velnati, S.; Centonze, S.; Girivetto, F.; Capello, D.; Biondi, R.M.; Bertoni, A.; Cantello, R.; Ragnoli, B.; Malerba, M.; Graziani, A.; et al. Identification of key phospholipids that bind and activate atypical PKCs. Biomedicines 2021, 9, 45. [CrossRef]

37. Ito, A.; Shimokawa, H.; Nakaike, R.; Fukai, T.; Sakata, M.; Takayanagi, T.; Egashira, K.; Takeshita, A. Role of protein kinase C-mediated pathway in the pathogenesis of coronary artery spasm in a swine model. Circulation 1994, 90, 2425-2431. [CrossRef]

38. Salamanca, D.A.; Khalil, R.A. Protein kinase C isoforms as specific targets for modulation of vascular smooth muscle function in hypertension. Biochem. Pharmacol. 2005, 70, 1537-1547. [CrossRef] [PubMed]

39. Budzyn, K.; Paull, M.; Marley, P.D.; Sobey, C.G. Segmental differences in the roles of rho-kinase and protein kinase C in mediating vasoconstriction. J. Pharmacol. Exp. Ther. 2006, 317, 791-796. [CrossRef]

40. Vono, R.; Fuoco, C.; Testa, S.; Pirro, S.; Maselli, D.; Ferland McCollough, D.; Sangalli, E.; Pintus, G.; Giordo, R.; Finzi, G.; et al. Activation of the pro-oxidant PKC $\beta 2$-p66Shc signaling pathway contributes to pericyte dysfunction in skeletal muscles of patients with diabetes with critical limb ischemia. Diabetes 2016, 65, 3691-3704. [CrossRef]

41. Chalfant, C.E.; Ohno, S.; Konno, Y.; Fisher, A.A.; Bisnauth, L.D.; Watson, J.E.; Cooper, D.R. A carboxy-terminal deletion mutant of protein kinase $\mathrm{C} \beta \mathrm{II}$ inhibits insulin-stimulated 2-deoxyglucose uptake in L6 rat skeletal muscle cells. Mol. Endocrinol. 1996, 10, 1273-1281. [CrossRef] [PubMed] 
42. Kouroedov, A.; Eto, M.; Joch, H.; Volpe, M.; Luscher, T.F.; Cosentino, F. Selective inhibition of protein kinase C $\beta 2$ prevents acute effects of high glucose on vascular cell adhesion molecule-1 expression in human endothelial cells. Circulation 2004, 110, 91-96. [CrossRef]

43. Nagaoka, T.; Kuo, L.; Ren, Y.; Yoshida, A.; Hein, T.W. C-reactive protein inhibits endothelium-dependent nitric oxide-mediated dilation of retinal arterioles via enhanced superoxide production. Investig. Ophthalmol. Vis. Sci. 2008, 49, 2053-2060. [CrossRef]

44. Singh, J.; Rattan, S. Role of PKC and RhoA/ROCK pathways in the spontaneous phasic activity in the rectal smooth muscle. Am. J. Physiol. Gastrointest. Liver Physiol. 2013, 304, G723-G731. [CrossRef]

45. Nagaoka, T.; Hein, T.W.; Yoshida, A.; Kuo, L. Simvastatin elicits dilation of isolated porcine retinal arterioles: Role of nitric oxide and mevalonate-rho kinase pathways. Investig. Ophthalmol. Vis. Sci. 2007, 48, 825-832. [CrossRef]

46. Cazzola, M.; Calzetta, L.; Rogliani, P.; Lauro, D.; Novelli, L.; Page, C.P.; Kanabar, V.; Matera, M.G. High glucose enhances responsiveness of human airways smooth muscle via the Rho/ROCK pathway. Am. J. Respir. Cell Mol. Biol. 2012, 47, 509-516. [CrossRef] [PubMed]

47. Doe, C.; Bentley, R.; Behm, D.J.; Lafferty, R.; Stavenger, R.; Jung, D.; Bamford, M.; Panchal, T.; Grygielko, E.; Wright, L.L.; et al. Novel Rho kinase inhibitors with anti-inflammatory and vasodilatory activities. J. Pharmacol. Exp. Ther. 2007, 320, 89-98. [CrossRef]

48. Kuo, L.; Davis, M.J.; Chilian, W.M. Longitudinal gradients for endothelium-dependent and -independent vascular responses in the coronary microcirculation. Circulation 1995, 92, 518-525. [CrossRef]

49. Kuo, L.; Chilian, W.M.; Davis, M.J. Interaction of pressure- and flow-induced responses in porcine coronary resistance vessels. Am. J. Physiol. 1991, 261, H1706-H1715. [CrossRef]

50. Kuo, L.; Davis, M.J.; Cannon, M.S.; Chilian, W.M. Pathophysiological consequences of atherosclerosis extend into the coronary microcirculation. Restoration of endothelium-dependent responses by L-arginine. Circ. Res. 1992, 70, 465-476. [CrossRef]

51. Hein, T.W.; Belardinelli, L.; Kuo, L. Adenosine $\mathrm{A}_{2 \mathrm{~A}}$ receptors mediate coronary microvascular dilation to adenosine: Role of nitric oxide and ATP-sensitive potassium channels. J. Pharmacol. Exp. Ther. 1999, 291, 655-664.

52. Bohlen, H.G. Protein kinase $\beta$ II in Zucker obese rats compromises oxygen and flow-mediated regulation of nitric oxide formation. Am. J. Physiol. Heart Circ. Physiol. 2004, 286, H492-H497. [CrossRef]

53. Shen, G.X. Selective protein kinase C inhibitors and their applications. Curr. Drug Targets Cardiovasc. Hematol. Disord. 2003, 3, 301-307. [CrossRef]

54. Wei, L.; Yin, Z.; Yuan, Y.; Hwang, A.; Lee, A.; Sun, D.; Li, F.; Di, C.; Zhang, R.; Cao, F.; et al. A PKC- $\beta$ inhibitor treatment reverses cardiac microvascular barrier dysfunction in diabetic rats. Microvasc. Res. 2010, 80, 158-165. [CrossRef] [PubMed]

55. Hein, T.W.; Omae, T.; Xu, W.; Yoshida, A.; Kuo, L. Role of arginase in selective impairment of endothelium-dependent nitric oxide synthase-mediated dilation of retinal arterioles during early diabetes. Investig. Ophthalmol. Vis. Sci. 2020, 61, 36. [CrossRef]

56. Heitzer, T.; Wenzel, U.; Hink, U.; Krollner, D.; Skatchkov, M.; Stahl, R.A.; MacHarzina, R.; Brasen, J.H.; Meinertz, T.; Munzel, T. Increased $\mathrm{NAD}(\mathrm{P}) \mathrm{H}$ oxidase-mediated superoxide production in renovascular hypertension: Evidence for an involvement of protein kinase C. Kidney Int. 1999, 55, 252-260. [CrossRef] [PubMed]

57. Soliman, H.; Gador, A.; Lu, Y.H.; Lin, G.; Bankar, G.; MacLeod, K.M. Diabetes-induced increased oxidative stress in cardiomyocytes is sustained by a positive feedback loop involving Rho kinase and PKC 32 . Am. J. Physiol. Heart Circ. Physiol. 2012, 303, H989H1000. [CrossRef]

58. Guzik, T.J.; Sadowski, J.; Guzik, B.; Jopek, A.; Kapelak, B.; Przybylowski, P.; Wierzbicki, K.; Korbut, R.; Harrison, D.G.; Channon, K.M. Coronary artery superoxide production and nox isoform expression in human coronary artery disease. Arterioscler. Thromb. Vasc. Biol. 2006, 26, 333-339. [CrossRef]

59. Siflinger-Birnboim, A.; Goligorsky, M.S.; Del Vecchio, P.J.; Malik, A.B. Activation of protein kinase C pathway contributes to hydrogen peroxide-induced increase in endothelial permeability. Lab. Investig. J. Tech. Methods Pathol. 1992, 67, 24-30.

60. Lu, G.; Greene, E.L.; Nagai, T.; Egan, B.M. Reactive oxygen species are critical in the oleic acid-mediated mitogenic signaling pathway in vascular smooth muscle cells. Hypertension 1998, 32, 1003-1010. [CrossRef]

61. Inoguchi, T.; Li, P.; Umeda, F.; Yu, H.Y.; Kakimoto, M.; Imamura, M.; Aoki, T.; Etoh, T.; Hashimoto, T.; Naruse, M.; et al. High glucose level and free fatty acid stimulate reactive oxygen species production through protein kinase C-dependent activation of NAD(P)H oxidase in cultured vascular cells. Diabetes 2000, 49, 1939-1945. [CrossRef] [PubMed]

62. Gaudry, M.; Combadiere, C.; Marquetty, C.; Sheibani, A.; el Benna, J.; Hakim, J. Dissimilarities in superoxide anion production by human neutrophils stimulated by phorbol myristate acetate or phorbol dibutyrate. Immunopharmacology 1990, 19, 23-32. [CrossRef]

63. Wojtera, E.; Konior, A.; Fedoryszak-Kuska, N.; Beresewicz, A. Obligatory role of intraluminal $\mathrm{O}_{2}^{-}$in acute endothelin-1 and angiotensin II signaling to mediate endothelial dysfunction and MAPK activation in guinea-pig hearts. Int. J. Mol. Sci. 2014, 15, 19417-19443. [CrossRef]

64. Zhang, C.; Xu, X.; Potter, B.J.; Wang, W.; Kuo, L.; Michael, L.; Bagby, G.J.; Chilian, W.M. TNF- $\alpha$ contributes to endothelial dysfunction in ischemia/reperfusion injury. Arterioscler. Thromb. Vasc. Biol. 2006, 26, 475-480. [CrossRef] [PubMed]

65. Baldus, S.; Koster, R.; Chumley, P.; Heitzer, T.; Rudolph, V.; Ostad, M.A.; Warnholtz, A.; Staude, H.J.; Thuneke, F.; Koss, K.; et al. Oxypurinol improves coronary and peripheral endothelial function in patients with coronary artery disease. Free Radic. Biol. Med. 2005, 39, 1184-1190. [CrossRef] [PubMed] 
66. Chen, Y.L.; Ren, Y.; Rosa, R.H., Jr.; Kuo, L.; Hein, T.W. Contributions of sodium-hydrogen exchanger-1 and mitogen-activated protein kinases to enhanced retinal venular constriction to endothelin-1 in diabetes. 2021. Available online: https://pubmed.ncbi. nlm.nih.gov/34353852/ (accessed on 20 August 2021).

67. Knock, G.A.; Ward, J.P. Redox regulation of protein kinases as a modulator of vascular function. Antioxid. Redox Signal. 2011, 15, 1531-1547. [CrossRef]

68. Wang, F.; Liu, H.M.; Irwin, M.G.; Xia, Z.Y.; Huang, Z.; Ouyang, J.; Xia, Z. Role of protein kinase C $\beta 2$ activation in TNF- $\alpha$-induced human vascular endothelial cell apoptosis. Can. J. Physiol. Pharmacol. 2009, 87, 221-229. [CrossRef]

69. Alvira, C.M.; Sukovich, D.J.; Lyu, S.C.; Cornfield, D.N. Rho kinase modulates postnatal adaptation of the pulmonary circulation through separate effects on pulmonary artery endothelial and smooth muscle cells. Am. J. Physiol. Lung Cell. Mol. Physiol. 2010, 299, L872-L878. [CrossRef] [PubMed]

70. Yao, L.; Romero, M.J.; Toque, H.A.; Yang, G.; Caldwell, R.B.; Caldwell, R.W. The role of RhoA/Rho kinase pathway in endothelial dysfunction. J. Cardiovasc. Dis. Res. 2010, 1, 165-170. [CrossRef]

71. Shimokawa, H.; Sunamura, S.; Satoh, K. RhoA/Rho-kinase in the cardiovascular system. Circ. Res. 2016, 118, 352-366. [CrossRef]

72. Li, Q.; Zhang, M.; Xuan, L.; Liu, Y.; Chen, C. Anagliptin inhibits neointimal hyperplasia after balloon injury via endothelial cell-specific modulation of SOD-1/RhoA/JNK signaling in the arterial wall. Free Radic. Biol. Med. 2018, 121, 105-116. [CrossRef]

73. Ohtsu, H.; Mifune, M.; Frank, G.D.; Saito, S.; Inagami, T.; Kim-Mitsuyama, S.; Takuwa, Y.; Sasaki, T.; Rothstein, J.D.; Suzuki, H.; et al. Signal-crosstalk between Rho/ROCK and c-Jun NH2-terminal kinase mediates migration of vascular smooth muscle cells stimulated by angiotensin II. Arterioscler. Thromb. Vasc. Biol. 2005, 25, 1831-1836. [CrossRef] [PubMed]

74. Ringvold, H.C.; Khalil, R.A. Protein kinase $\mathrm{C}$ as regulator of vascular smooth muscle function and potential target in vascular disorders. Adv. Pharmacol. 2017, 78, 203-301. [CrossRef]

75. Thengchaisri, N.; Kuo, L. Hydrogen peroxide induces endothelium-dependent and -independent coronary arteriolar dilation: Role of cyclooxygenase and potassium channels. Am. J. Physiol. Heart Circ. Physiol. 2003, 285, H2255-H2263. [CrossRef]

76. Hein, T.W.; Zhang, C.; Wang, W.; Chang, C.I.; Thengchaisri, N.; Kuo, L. Ischemia-reperfusion selectively impairs nitric oxidemediated dilation in coronary arterioles: Counteracting role of arginase. FASEB J. 2003, 17, 2328-2330. [CrossRef]

77. Kuo, L.; Davis, M.J.; Chilian, W.M. Myogenic activity in isolated subepicardial and subendocardial coronary arterioles. Am. J. Physiol. 1988, 255, H1558-H1562. [CrossRef]

78. Chilian, W.M. Microvascular pressures and resistances in the left ventricular subepicardium and subendocardium. Circ. Res. 1991, 69, 561-570. [CrossRef] [PubMed]

79. Potts, L.B.; Ren, Y.; Lu, G.; Kuo, E.; Ngo, E.; Kuo, L.; Hein, T.W. Constriction of retinal arterioles to endothelin-1: Requisite role of rho kinase independent of protein kinase C and L-type calcium channels. Investig. Ophthalmol. Vis. Sci. 2012, 53, $2904-2912$. [CrossRef] [PubMed]

80. Wang, Y.; Zhou, L.; Su, W.; Huang, F.; Zhang, Y.; Xia, Z.Y.; Xia, Z.; Lei, S. Selective inhibition of PKC $\beta 2$ restores ischemic postconditioning-mediated cardioprotection by modulating autophagy in diabetic rats. J. Diabetes Res. 2020, 2020, 2408240. [CrossRef]

81. Liu, Y.; Bubolz, A.H.; Mendoza, S.; Zhang, D.X.; Gutterman, D.D. $\mathrm{H}_{2} \mathrm{O}_{2}$ is the transferrable factor mediating flow-induced dilation in human coronary arterioles. Circ. Res. 2011, 108, 566-573. [CrossRef]

82. Zhang, C.; Hein, T.W.; Wang, W.; Kuo, L. Divergent roles of angiotensin II $\mathrm{AT}_{1}$ and $\mathrm{AT}_{2}$ receptors in modulating coronary microvascular function. Circ. Res. 2003, 92, 322-329. [CrossRef]

83. Thengchaisri, N.; Shipley, R.; Ren, Y.; Parker, J.; Kuo, L. Exercise training restores coronary arteriolar dilation to NOS activation distal to coronary artery occlusion: Role of hydrogen peroxide. Arterioscler. Thromb. Vasc. Biol. 2007, 27, 791-798. [CrossRef] [PubMed]

84. Hein, T.W.; Qamirani, E.; Ren, Y.; Xu, X.; Thengchaisri, N.; Kuo, L. Selective activation of LOX-1 mediates C-reactive protein evoked endothelial vasodilator dysfunction in coronary arterioles. Circ. Res. 2014, 114, 92-100. [CrossRef] [PubMed] 